Article

\title{
Climate Change Policies and the Carbon Tax Effect on Meat and Dairy Industries in Brazil
}

\author{
Augusto Mussi Alvim ${ }^{1, *(1)}$ and Eduardo Rodrigues Sanguinet ${ }^{2}(\mathbb{D}$ \\ 1 Escola de Negócios, Pontifícia Universidade Católica do Rio Grande do Sul, Porto Alegre 90619-900, Brazil \\ 2 Instituto de Economía Agraria, Universidad Austral de Chile, Valdivia 509000, Chile; \\ eduardo.sanguinet@uach.cl \\ * Correspondence: augusto.alvim@pucrs.br
}

check for updates

Citation: Alvim, A.M.; Sanguinet, E.R. Climate Change Policies and the Carbon Tax Effect on Meat and Dairy Industries in Brazil. Sustainability 2021, 13, 9026. https://doi.org/ $10.3390 /$ su13169026

Academic Editors: Dario Siggia and Ashutosh Kolte

Received: 30 June 2021

Accepted: 4 August 2021

Published: 12 August 2021

Publisher's Note: MDPI stays neutral with regard to jurisdictional claims in published maps and institutional affiliations.

Copyright: (c) 2021 by the authors. Licensee MDPI, Basel, Switzerland. This article is an open access article distributed under the terms and conditions of the Creative Commons Attribution (CC BY) license (https:// creativecommons.org/licenses/by/ $4.0 /)$.

\begin{abstract}
This study analyzes the impacts of reducing greenhouse gas (GHG) emissions on the meat and dairy industries. To achieve this goal, the Global Trade Analysis Project (GTAP) database was used in a Computable General Equilibrium (CGE) setting, which allows for the inclusion of carbon taxes and the definition of four alternative environmental policies scenarios using both Global Warming Potential (GWP) and Global Temperature Potential (GTP) as GHG emissions measures. All scenarios analyze the main effects of carbon-based tax economic instruments on the industry and national production, trade, and emissions, comparing the results for different measures of GHG, GWP, and GTP from the Greenhouse Gas Emissions Estimation System (SEEG) sectoral Brazilian emissions database. In contrast with other industries, relatively lower taxes on the meat and dairy industries seem to be the most adequate in terms of cost distribution in the Brazilian economic structure when only the GWP measure is considered. Urban activities and less-methane-intensive industries benefit from climate change policies designed using GWP-based rather than GTP-based carbon taxes. The article also highlights the importance of a gradual introduction of carbon taxes, allowing the most vulnerable industries a transition moment to adopt clean technologies and/or redirect economic activity to less-GHG-emitting segments.
\end{abstract}

Keywords: GHG emissions; carbon taxes; meat and dairy industries

\section{Introduction}

Over the last decade, Brazil has experienced substantial economic growth in agriculture and food processing, maintaining a leading position in international trade. Therefore, Brazilian agribusiness exports were U.S. \$101 billion and equivalent to $45 \%$ of the total exported by Brazil in 2020, with more than 55\% destined for China, the European Union (27), and the United States [1].

Agriculture and the agri-food industry are also significant sources of anthropogenic greenhouse gas (GHG) emissions, with the meat and dairy industries being particularly emissions-intensive [2]. As an example of this, the meat and dairy industries account for $29 \%$ of the Brazilian GHG emissions [3]. Similarly, grain production (mainly soy and corn as the basis of animal feed) is often associated with deforestation, animal production, and biofuel [4-6].

On the demand side, climate change concerns have pressured governments and multilateral organizations to establish goals for reducing GHG emissions, typically based on carbon dioxide $\left(\mathrm{CO}_{2}\right)$ equivalent footprint measures [2,7-9]. However, some of the adopted targets and the applied GHG index in environmental agreements could penalize economies with comparative advantages in the agri-food sector, especially the meat and dairy industries [10-13].

Nowadays, the main GHG emission index is the Global Warming Potential (GWP). However, in ruminant production (meat and dairy), the standardized GWP index undervalued the immediate impacts of temperature. Further, it overestimated the effect of methane 
emissions in the short run, disregarding the fact that the lifetime effect on atmospheric warming is considerably lower than appraised [14]. Even though there is a growing body of literature on GHG emissions from agri-food industries [15-22], disregard for sectoral differences in the composition of GHG metrics can lead to biased conclusions about the environmental responsibility of economies specializing in ruminant production. Although the implications of these are straightforward, there remains a lack of comparative assessments in the literature [2,9]. Moreover, there is a trend towards regulating carbon markets claimed by multilateral organizations to mitigate environmental impacts. However, there is a gap in the institutional regulation framework in Brazil, which requires empirical evidence to contribute to policy-making [23]. This study addresses these issues by adding to the existing literature's economic and environmental results based on simulations of carbon market policies, further providing novel measures comparing GTP and GWP for the meat and dairy industries.

The Brazilian GWP-based emission reduction targets in the Paris Agreement were ratified in 2015 [24]. However, the Brazilian environmental policy fails to consolidate a straightforward carbon-market-based approach for meat and dairy industry production, unlike other competitors such as Australia, Finland, Mexico, South Africa, and Canada [12]. Specifically, the leading Brazilian environmental policy is based on regulatory legislation [24-26].

In a seemingly contradictory way, the Brazilian agriculture policy supports the production and export of non-environmentally friendly agri-food products with a set of financial instruments, such as rural credit, minimum prices rules, and low-interest rates $[1,25,27]$. Specifically, in the Amazon, Cerrado, Mata Atlantica, and Pantanal biomes, the effects of livestock activity upon deforestation are considerably underestimated, and there are no mechanisms to effectively discourage emissions from the meat producer side $[24,28,29]$.

Accordingly, this paper aims to estimate the impacts of the implementation of carbonbased taxes as climate change policies on the economic and environmental outcomes, such as production, trade, and GHG emissions, of the meat and dairy industries in Brazil. The contribution is twofold. First, this study provides ex-ante estimates of taxation policies in the short-term carbon market for production and trade, useful to Brazil's policymakers, that are generally based on regulatory instruments rather than taxation of production (economic instruments). Second, it presents the different measures of GHG emissions indexes on Brazilian economic sectors: the leading GWP and the Global Temperature Potential (GTP). Although the GWP is the standard indicator defined in the Paris Agreement, the present study considers the GTP in order to disclose the trade-offs between the economic and environmental impacts for the meat and dairy industry.

Ex-ante assessments of climate change policies are particularly relevant for policymakers, especially considering the systemic effects on the whole economic structure [30]. In this regard, to highlight the potential impacts of carbon-based policies on the Brazilian meat and dairy industries, this study focuses on the economic and environmental outcomes of four alternative scenarios. Furthermore, we add a comparison of GTP and GWP targets indexes to the existing GHG literature, providing further ex-ante forecasting evidence from a systematic interconnected economic and environmental systems computable general equilibrium (CGE) analysis.

The methodological framework was adopted to allow for the systematic evaluation of trade-offs between environmental impacts and economic and/or regulatory instruments on the production side [30-32]. This study adopted the static Global Trade Analysis Project (GTAP) version 9 model and incorporated an environmental extension for comparing GWP and GTP $\mathrm{CO}_{2}$-related metrics. There are alternative versions of GTAP with endogenously imputed GHG emissions-for example, GTAP-E, GTAP- $\mathrm{CO}_{2}$, GTAP-Power, and GTAP-BIO [33-35]. However, these extensions do not have the GTP index. To get around this, the traditional economic GTAP database was adopted, linking the results with specific coefficients from the Greenhouse Gas Emissions Estimation System (SEEG) sectoral Brazilian emissions database, which presents statistics for both GWP and GTP [36]. 
GHG emission coefficients were used for both measures and linked to economic results for scenario simulations.

Two groups of alternative policies associated with Brazil's meat and dairy production were assembled to generate evidence about the potential trade-offs between the maintenance of regulatory policies and those based on carbon market taxes. The first group comprises economic instruments (carbon-based market taxes), focused on the hypothetical inclusion of tax mechanisms in the meat industry's production in the context of the absence of this type of instrument in Brazilian environmental policy. The second group comprises flexible command and control instruments (as a regulation policy) according to central policy measures for the production side $[6,28,37,38]$. The comparative assessment of both groups provides useful elements relevant to the debate on Brazilian carbon policies for the meat and dairy industry toward an environmentally and economically complementary policy.

This article is structured as follows. The following section presents the background to agriculture and GHG metrics and Brazilian environmental policies. The third section describes the method and the CGE model adopted. The fourth section presents the main results and policy implications of climate change, emphasizing the Brazilian meat and dairy industries. The last section presents the main conclusions of the study.

\section{Background}

This study is focused on two issues related to Brazil and climate change. First, it emphasizes the potential penalization of the meat and dairy industry in accounting for GHG measures, mainly due to the positive correlation between methane emissions from extensive livestock production and the standardized use of GWP indicators. It also compares the different atmospheric trends effects over time for GWP and GTP. Those differences between the two indicators are significant and may affect Brazil's strategies in developing environmental policies to mitigate GHG emissions [7,8]. Second, it claims that the lack of economic instruments in carbon-based market taxation can also negatively impact the meat and dairy industry's sustainability associated with mitigation and adaptation measures for reducing global warming. Nevertheless, empirical evidence suggests the potential benefits of imposing a tax on the externalities of the meat production chain, which could point to essential directions for Brazilian environmental policy [12,26,29,35,39].

\subsection{Agriculture and GHG Metrics}

There are different ways to measure atmospheric warming, often determined by the time effect over the climate change. In this case, the equivalence of $\mathrm{CO}_{2}$ footprints neglects the relationship between the total amount of emissions and the time effect related to the atmosphere $[2,9,32]$. This has the potential to considerably distort the comparative advantage between countries, as it penalizes beef and dairy production and trade. The ruminant production emissions based on the standard GWP measure undervalue the immediate impacts on the atmospheric temperature, as well as the variation (increase or decrease) in the number of animals releasing methane $\left(\mathrm{CH}_{4}\right)[9,40,41]$.

The $\mathrm{CH}_{4}$ emission cycle starts with feeding pasture and/or grains, absorbing the atmospheric carbon in the soil, food, and animals. This cycle ends with the $\mathrm{CO}_{2}$ and $\mathrm{CH}_{4}$ emissions in the atmosphere. Briefly, there is a positive emission of $\mathrm{CO}_{2}$ equivalent from beef and dairy production. However, unlike the $\mathrm{CH}_{4}$ emissions from ruminants, the $\mathrm{CH}_{4}$ of fossil origin would remain for thousands of years, contributing to a more significant greenhouse effect [14]. Therefore, the GWP overestimates the impacts of meat and dairy industry emissions over time. To overcome this limitation, the Global Temperature Change (GTP) concept incorporates the time horizon for an emission pulse [42]. Countries with intense livestock activity need to consider GTP measures to compensate for the temporal dimension of the climate system balance that is neglected by GWP measures and can help to assess short-lived emissions, unlike the $\mathrm{CH}_{4}$ associated with ruminant production [43]. 
Despite these differences, it is possible to establish the relative importance of emissions per heating unit or global warming impact [42,43]. This comparison makes it possible to demonstrate the relative importance of the different production sectors responsible for emissions. Comparisons per unit with carbon dioxide in Brazil between 2005 and 2018 are shown in Table 1. It is possible to identify the GWP and GTP metrics and relative variations over time. Additionally, the GWP is defined as the integrated value of an emission pulse's cumulative effects at a specific time during the subsequent period indicated (sometimes 20 or 100 years) [14].

Table 1. GWP and GTP emissions from all industries (tons) and growth (\%) during the period 2005-2018-Brazil.

\begin{tabular}{lcccccc}
\hline \multirow{2}{*}{ SEEG Sectors } & \multicolumn{2}{c}{ 2005 } & & \multicolumn{2}{c}{$\mathbf{2 0 1 8}$} & \multicolumn{2}{c}{ (2005-2018) } \\
\cline { 2 - 7 } & GWP (t.) & GTP (t.) & GWP (t.) & GTP (t.) & GWP & GTP \\
\hline Meat \& Dairy & $400,022,781$ & $114,435,703$ & $408,675,212$ & $117,924,190$ & 2 & 3 \\
\hline Deforestation ${ }^{1}$ & $2,068,426,095$ & $1,989,495,796$ & $827,043,560$ & $794,106,885$ & -60 & -60 \\
\hline Grains \& Crops & $94,537,522$ & $48,417,779$ & $146,699,271$ & $83,439,144$ & 55 & 72 \\
\hline Industry \& Services $^{2}$ & $115,122,063$ & $78,806,916$ & $148,787,577$ & $93,671,081$ & 29 & 19 \\
\hline Energy & $331,843,307$ & $315,180,572$ & $424,803,865$ & $407,694,211$ & 28 & 29 \\
\hline Carbon Sequestration & $-446,394,750$ & $-446,394,750$ & $-529,451,505$ & $-529,451,505$ & 19 & 19 \\
\hline Total & $2,563,557,019$ & $2,099,942,016$ & $1,426,557,980$ & $967,384,005$ & -44 & -54 \\
\hline
\end{tabular}

Note: ${ }^{1}$-Change in land use plus forest waste. ${ }^{2}$-Industrial processes plus solid waste. Source: SEEG, 2019.

Therefore, GWP accumulates the effects over time but disregards emissions after that determined period. The GTP indicates the temperature for a selected year without weights for years before or after the selected year (IPCC, 2013). Accordingly, the most significant GHG emitter was deforestation, followed by the Energy and Meat \& Dairy industries, considering the GWP and GTP indicators in 2018. For both indicators, it can be noted that Brazil has already met its Paris Agreement target for 2030. Even though Brazil's deforestation significantly decreased until 2018, all other sectors increased their GHG emissions.

The differences between GWP and GTP indicators may affect Brazilian strategies for building efficient environmental policies to mitigate GHG emissions [7,8,19]. It can be noted that related urban activities increased their GHG emissions over time. For example, the Energy and Industry \& Services sectors increased their emissions by $28.0 \%$ (29.4\%) and $29.2 \%(18.2 \%)$ for GWP and GTP, respectively. In turn, agriculture activities increased the emissions of the Meat \& Dairy and Grains \& Crops sectors by $2.2 \%$ (3.0\%) and 55.2\% (72.3\%) between 2005 and 2018, respectively. Interestingly, there was a reduction in deforestation emissions and an increase in carbon sequestration.

Despite these differences, GWP is the most used indicator in the climate change literature and multilateral agreements [2,31]. On average, the world's animal production is estimated to account for $15 \%$ of GHG emissions, $80 \%$ of which originate from ruminant animal systems [8]. For example, in Brazil, animal production represents $29 \%$ of GWP emissions, $94 \%$ of which was related to ruminant production in 2018 [44].

Any political decision associated with an increase in methane emissions from agriculture (or manufacturing) would potentially be more damaging, depending on the indicator applied to mitigate the adverse effects of global warming. Therefore, the compensation for reducing emissions in different economic sectors-which have different GHG coefficients — can be considered relevant to the Brazilian environmental policy debate [27]. 


\subsection{Brazilian Environmental Policy}

Recently, Brazil has made progress in its recovery of deforested areas. The reduction in degraded areas in the Amazon, Cerrado, Atlantica, and Pantanal biomes during the same period allowed for a significant reduction in GHG emissions [25,45]. The Action Plan for Prevention and Control of Deforestation in the Legal Amazon [46] and the Action Plan for the Prevention and Control of Deforestation and Burning in the Cerrado [47] are mainly responsible for these positive results. In addition, the country has also implemented the $\mathrm{ABC}$ Plan and the RenovaBio program to reduce emissions from agriculture and energy use, although these have been less effective at reducing the total amount of GHG emissions.

The ABC Plan aims to adopt sustainable production technologies with the potential to reduce GHG emissions in the agricultural sector [48]. On the other hand, the RenovaBio program seeks to increase biofuel production and expand the internal energy supply (IPEA, 2019). Although relevant, these environmental policies are less useful in reducing GHG emissions from livestock activities and agribusiness. Indeed, the sustainability of the Brazilian meat industry may be penalized by the lack of precise economic instruments in the country's carbon market $[2,12,29]$.

The growing role of agriculture in the Brazilian economy and trade requires more intensive use of natural resources and a probable expansion of the cultivated area. These aspects should continue to increase carbon emissions, increase deforestation, and use soils less suitable for agricultural production [49].

In this context, it is necessary to advance the debate on complementary policy instruments to protect the sustainability of Brazilian agribusiness. Since the regulatory mechanisms commonly adopted are less effective, there arises an opportunity to discuss the introduction of alternative measures, of which carbon taxes can be highlighted [12,39]. Therefore, this issue is addressed by incorporating the simulation of economic instruments compared to regulatory ones, identifying the main trade-offs between economic and environmental impacts and GTP metrics, as detailed in the next section.

\section{Materials and Methods}

In order to analyze the effects of the implementation of a carbon-based tax on production, trade, and GHG emissions for the Brazilian economy, this study considers a static Computable General Equilibrium (CGE) model. The Global Trade Analysis Project (GTAP) is an applied multiregional model that assumes constant returns to scale and perfect competition in production and consumption activities [50]. Therefore, analyzing an arbitrary region and its relationships with other regions can explain the global economy by imposing equilibrium conditions between international agents. Industries use primary factors and intermediate inputs, both locally produced and imported, in each region [50-52]. The regional, industrial, and primary factor aggregation settings used in this study are shown in Table 2. The initial equilibrium was characterized by the baseline scenario representing the economy in 2011 according to the GTAP version 9 database. Thus, the GTAP makes it possible to build regional and sectorial aggregations in line with empirical objectives. The calibrated database is from input-output (IO) tables, being consistent with empirical experiments such as those performed in our study. In this regard, the original GTAP9 database has two groups of regions associated with Europe: (1) the EU25; and (2) the rest of Europe. Therefore, we considered this original structure of the GTAP base in the regional aggregation, and we included in the Rest of the World (RoW) those countries in Europe that are not part of the EU25. In our case, it is particularly relevant that some countries be disaggregated for a better analysis of the results. For example, Brazil, Argentina, China, Russia, and the United States were selected as strategic countries for the world's production and because they carry out significant trade exchanges with Brazil in the meat and dairy sectors. Regarding economic sectors, aggregation was based on simulated carbon tax policy shocks, which are directly and indirectly associated with higher levels of intensity in emissions (energy and forestry, for example), sectors of empirical interest (meat and 
related products, grains, and activities related to agriculture), and linked sectors, such as the Industry \& Services sector.

Table 2. Regions, industries, and primary factors in the GTAP model.

\begin{tabular}{lll}
\hline \multicolumn{1}{c}{ Regions } & \multicolumn{1}{c}{ Industries } & \multicolumn{1}{c}{ Primary Factors } \\
\hline Africa (AFR) & Cattle production (BECA) & \\
Argentina (ARG) & Chicken and pork production & \\
Brazil (BRA) & (CIPO) & \\
China (CHN) & Raw Milk production (RMIL) & Capital \\
East Asia (EAS) & Other Agriculture (OTAG) & Land \\
EU-25 (EUR) & Forestry (FORE) & Natural Resources \\
Canada and Mexico (NAM) & Beef-industry (BEEF) & Skilled Labor \\
Oceania (OCE) & Chicken and pork-industry & Unskilled Labor \\
Russia (RUS) & (CHPO) & \\
South Asia (SAS) & Dairy-industry (DAIR) & \\
Southeast Asia (STA) & Industry \& Services (INSE) & \\
United States (USA) & Energy (ENER) & \\
Rest of the World (ROW) & & \\
Source: GTAP 9. & &
\end{tabular}

The impact of carbon-based taxation on production, trade, and GHG emissions (accounted for in terms of GWP and GTP) was assessed according to the simulation of the four alternative policy scenarios described in Table 3. Overall, it was assumed that the policy implementation aims to reduce GHG emissions in Brazil by applying a tax to the producer side. Therefore, two environmental policy instruments were considered: (1) economic instruments (EIs) (carbon-based taxes); and (2) flexible command and control instruments (FCCIs) (without taxation). The latter instruments (FCCIs) are currently adopted in Brazil, basically focused on institutional regulation, and are further considered in the baseline scenario.

Table 3. Descriptions of alternative scenarios by different carbon taxes (COP21).

\begin{tabular}{|c|c|c|c|c|c|}
\hline & Scenarios & Description & Deforestation & $\begin{array}{l}\text { Mitigation in the } \\
\text { Agricultural } \\
\text { Sector in Brazil }\end{array}$ & $\begin{array}{c}\text { Mitigation in } \\
\text { Other Sectors } \\
\text { in Brazil }\end{array}$ \\
\hline (1) & COP21-MEAT & $\begin{array}{l}\text { Carbon taxes apply to the } \\
\text { Brazilian Meat \& Dairy } \\
\text { industry. (EI) }\end{array}$ & $\begin{array}{l}\text { The same level of } \\
\text { carbon sequestration as } \\
\text { the base scenario. } \\
\text { (flexible command and } \\
\text { control instruments). }\end{array}$ & $\begin{array}{l}\text { YES } \\
(20,40,60 \$ / t)\end{array}$ & NO \\
\hline (2) & COP21-ENERGY & $\begin{array}{l}\text { Carbon taxes are applied to } \\
\text { the Brazilian Energy } \\
\text { industry. (EI). }\end{array}$ & $\begin{array}{l}\text { The same level of } \\
\text { carbon sequestration as } \\
\text { the base scenario. } \\
\text { (flexible command and } \\
\text { control instruments). }\end{array}$ & $\mathrm{NO}$ & $\begin{array}{l}\text { YES } \\
(20,40,60 \$ / t)\end{array}$ \\
\hline (3) & COP21-All INDUSTRIES & $\begin{array}{l}\text { Carbon taxes are applied to } \\
\text { all sectors in Brazil. }\end{array}$ & $\begin{array}{l}\text { The same level of } \\
\text { carbon sequestration as } \\
\text { the base scenario. } \\
\text { (flexible command and } \\
\text { control instruments). }\end{array}$ & $\begin{array}{l}\text { YES } \\
(20,40,60 \$ / t)\end{array}$ & $\begin{array}{l}\text { YES } \\
(20,40,60 \$ / t)\end{array}$ \\
\hline (4) & COP21-MEAT \& DAIRY & $\begin{array}{l}\text { Carbon taxes: lower } \\
\text { taxes on the Meat \& } \\
\text { Dairy industry. }\end{array}$ & $\begin{array}{l}\text { The same level of } \\
\text { carbon sequestration as } \\
\text { the base scenario. } \\
\text { (flexible command and } \\
\text { control instruments). }\end{array}$ & $\begin{array}{l}\text { YES } \\
(20,40 \$ / t)\end{array}$ & $\begin{array}{l}\text { YES } \\
(40,60 \$ / t)\end{array}$ \\
\hline
\end{tabular}


The four scenarios consider only the application of different carbon-based taxes to Brazilian industries, keeping the same agricultural and environmental policies as in the base scenario (see also [24,28,53]).

(a) Scenario 1 reflects the application of carbon taxes to the Meat \& Dairy industry and zero-carbon taxes to the other sectors in Brazil.

(b) Scenario 2 includes only carbon taxes on the Energy industry.

(c) Scenario 3 simulates equal carbon taxes on all industries $(\$ 20, \$ 40$, and $\$ 60$ per $t$. of $\mathrm{CO}_{2}$ ), though no carbon taxes apply to the forestry sector.

(d) Scenario 4 considers the application of carbon taxes to the Meat \& Dairy and Grains \& Crops sectors lower than those applied to the Energy and Industry \& Services sectors.

\subsection{Carbon Taxes}

Regarding the environmental aspect, two points must be considered in order to calculate the carbon taxes on Brazil using GWP and GTP measures (see also [54]). First, the total GHG emissions from production are obtained from [44] in terms of GWP or GTP. Particularly, the SEEG estimations include all sources of GHG emissions by sector, following the IPCC guidelines. For example, in the agricultural sector all anthropogenic emissions are considered, including Non- $\mathrm{CO}_{2}\left(\mathrm{CH}_{4}\right.$ and $\left.\mathrm{N}_{2} \mathrm{O}\right)$. The agricultural sector is subdivided into BECA, CIPO, RMIL, and OTAG in this paper. Changes in land use are also considered separately and are associated with land cover and vegetation change calculated through satellite monitoring. These include emissions and the removal of $\mathrm{CO}_{2}$ by land use changes as well as estimates of emissions from forest waste. In this study, land use changes are included in the forestry sector (FORE). More details can be found in [36]). These data show the total GHG emissions for each industry in the base scenario as described in Table 1. For instance, the total carbon emissions, in terms of GWP or GTP, are the sum of the total GHG carbon emissions in the production for selected industries as described in Table 2. It is assumed that the GTAP equivalent shock value (\%) is related to the price of the GHG emissions or the carbon taxes applied on the supply side. These carbon taxes are calculated as the percentage ratio between the value of carbon emissions (tons of carbon emissions multiplied by the price of carbon emissions per ton) and the production value of each industry. The carbon taxes also represent a cost-benefit relation, a ratio between the cost value of GHG emissions and the total production value by selected sectors [55].

Second, the used prices for carbon emissions are $\$ 20 / t, \$ 40 / t$, and $\$ 60 / t$ (Tables 4 and 5) as observed in the studies [12,26,56]. In this way, GTAP model version 9 is extended to incorporate the environmental component related to GHG emissions based on GWP and GTP emissions. Emissions data on the Brazilian industrial supply side were obtained from the Greenhouse Gas Emissions Estimation System (SEEG) for the base year 2011. Finally, the industrial output, emissions, and trade measures were obtained from GTAP version 9, allowing for an analysis of welfare, production, trade, and emissions.

Table 4. The equivalent shock on GTAP using GWP (\%) by sector.

\begin{tabular}{cccc}
\hline \multicolumn{4}{c}{ Equivalent Shock (\%) } \\
\hline Sector & 10 \$ GHG (t.) & 20 \$/GHG (t.) & 40 \$/GHG (t.) \\
\hline BECA & 10.76 & 21.53 & 43.05 \\
\hline CIPO & 0.91 & 1.83 & 3.66 \\
\hline RMIL & 4.20 & 8.40 & 16.80 \\
\hline BEEF & 0.03 & 0.05 & 0.10 \\
\hline CHPO & 0.03 & 0.06 & 0.12 \\
\hline DAIR & 0.08 & 0.17 & 0.34 \\
\hline
\end{tabular}


Table 4. Cont.

\begin{tabular}{cccc}
\hline & \multicolumn{3}{c}{ Equivalent Shock (\%) } \\
\hline OTAG & 0.84 & 1.68 & 3.36 \\
\hline INSE & 0.04 & 0.07 & 0.15 \\
\hline ENERG & 3.50 & 6.90 & 13.9 \\
\hline Source: Calculated by the authors. & &
\end{tabular}

Source: Calculated by the authors.

Table 5. The equivalent shock on GTAP using GTP (\%) by sectors.

\begin{tabular}{cccc}
\hline \multicolumn{4}{c}{ Equivalent Shock (\%) } \\
\hline Sectors & 10 \$ GHG (t.) & 20 \$ GHG (t.) & 40 \$ GHG (t.) \\
\hline BECA & 2.87 & 5.74 & 11.47 \\
\hline CIPO & 0.47 & 0.95 & 1.89 \\
\hline RMIL & 1.48 & 2.96 & 5.91 \\
\hline BEEF & 0.00 & 0.01 & 0.01 \\
\hline CHPO & 0.00 & 0.01 & 0.02 \\
\hline DAIR & 0.01 & 0.02 & 0.05 \\
\hline OTAG & 0.45 & 0.90 & 1.79 \\
\hline INSE & 0.03 & 0.05 & 0.10 \\
\hline ENERG & 3.30 & 6.70 & 13.40 \\
\hline
\end{tabular}

Source: Calculated by the authors.

Tables 4 and 5 show the carbon taxes applied, considering GTP and GWP as measures of GHG emissions, to selected sectors. The carbon taxes were applied to the supply side, simulating an equivalent shock on GTAP in terms of percentage. The carbon tax values (the equivalent shock in GTAP) were applied to the production function as an additional tax in percentage terms [24,28].

Based on Tables 4 and 5, three aspects can be highlighted. The first is that the percentage values for the Beef (BECA), Milk (RMIL), and Energy (ENER) sectors are higher than those for the other sectors for both measures (GWP and GTP). The second aspect is that, by using GWP, the carbon taxes (\%) are significantly higher for Beef (BECA) and Milk (RMIL) production when considering the same carbon price per ton. For example, for a price of $\$ 10$ per ton of GHG, the percentage rate for BECA emissions using GWP is $10.8 \%$ and that using GTP is $2.9 \%$. This is because GWP assigns a greater weight to methane gas emissions than GTP. Finally, the Energy sector has approximately the same percentage values for both GHG measures (GWP and GTP).

Another interesting aspect is that the chicken and pork (CIPO) sector has a significantly lower tax value than the ruminant sectors (BECA and RMIL) for both emissions measures. This results in a smaller and more favorable tax difference for the chicken and pork (CIPO) sector in all scenarios. The agro-industrial and Beef industries have the lowest tax values, regardless of the type of meat processed.

Finally, it is important to highlight that no carbon taxes were applied to GHG emissions in the Forestry sector. It was considered that the same measures (FCCIs) as in the base scenario were used to control and preserve the Forestry sector.

\subsection{Closure and Channel Effects}

Economic theory suggests that raising the price of normal goods and services with a tax reduces the demand for them. Pigou [57] proposed using taxes to internalize negative externalities and showed that a direct tax on polluting activity is the most efficient tax instrument for reducing environmental damage. Similarly, the effect of an environmental tax on carbon emissions from productive activities will depend on the implemented ap- 
proach, the economic structure, consumer preferences, and other sociopolitical factors [58]. In these simulations, short-term closing was considered. Additionally, carbon taxes based on the origin of the emissions or upon the production level were applied, making it possible to identify the different effects on production output and trade in other economic industries (Figure 1).

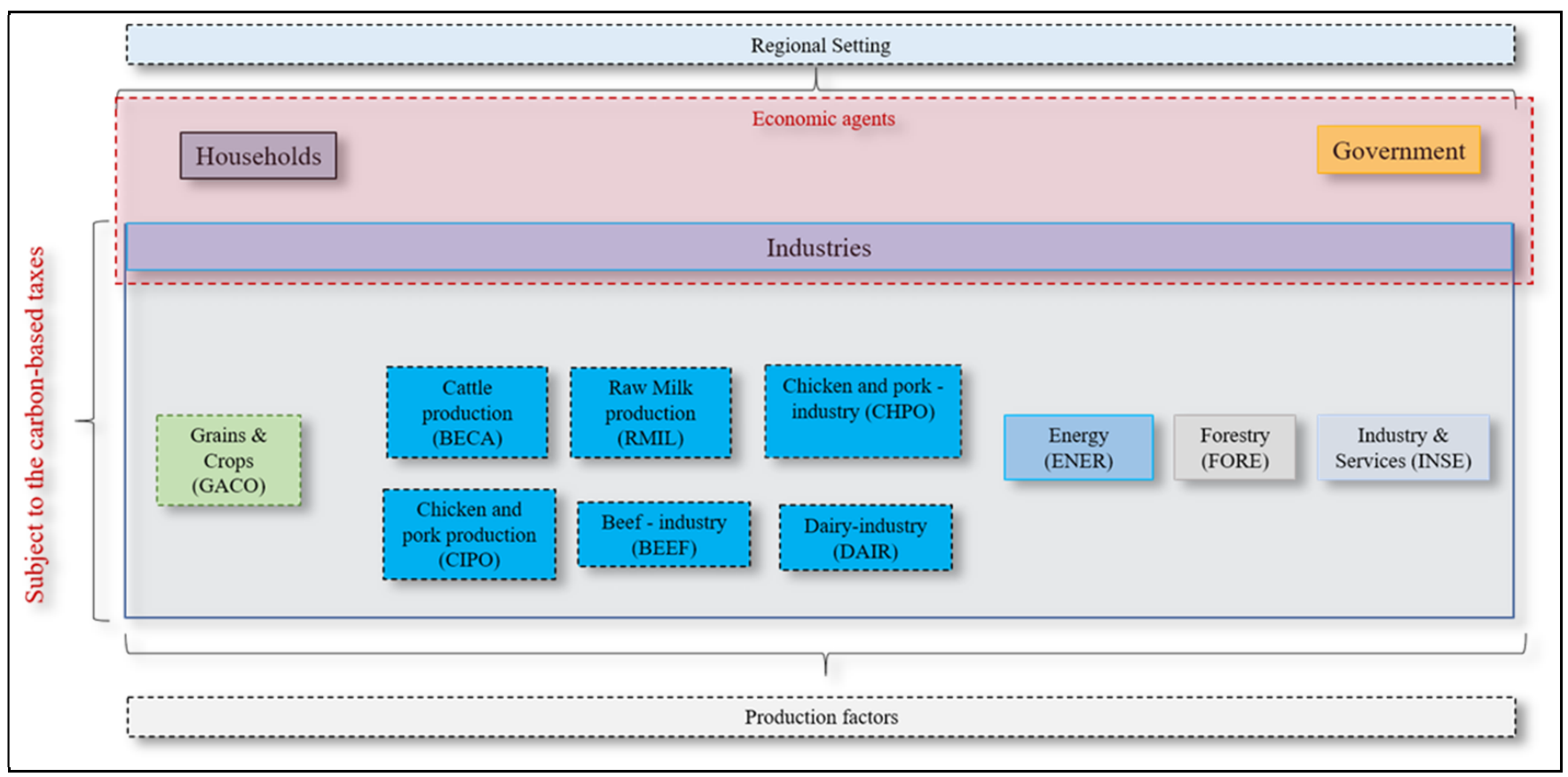

Figure 1. Diagram illustrating the carbon tax model in a stylized GTAP setting. The blue boxes represent the Meat \& Dairy sectors. The economic sectors are modeled so that the output is intense in emissions. Therefore, it can be assumed that the emissions released during production are incorporated into production and trade by all economic agents of the GTAP model since all agents directly or indirectly use or burn fossil fuels that release GHG emissions.

From the producer side, a FCCI is not effective at reducing methane emissions from animal production. However, as a carbon pricing mechanism covering emissions, the level of prices and taxes imposed by the government changes with EI policies. According to [35], the government revenue increases more when applying carbon taxes to production and export than when applying carbon taxes to consumers and import goods. Within the scope of GTAP, this argument suggests that countries that export carbon-intensive commodities, such as Brazil, cause three possible types of effects:

(a) Pigou's well-being: there is an efficiency gain associated with the decrease in the consumption of the polluting good concerning the marginal external cost of pollution and the change in the price of the polluting good;

(b) Tax interaction: environmental policies increase the price of polluting products related to household leisure and create market distortions;

(c) Revenue feedback: when environmental tax revenue is recycled through cuts in (other) marginal tax rates, this reduces the distortion caused by pre-existing taxes, improving the level of well-being.

The following section presents the results considering the alternative scenarios defined in this section. Initially, the effects of tariffs and their impact on changes in carbon emissions are shown. Later, the effects of these carbon tariffs on meat and dairy exports and Brazil's GDP are assessed. 


\section{Results}

This section presents the estimated impacts of the carbon tax policy on the Brazilian national economy in the four alternative scenarios. The GTAP model is used to simulate the economic impacts of industrial emissions restrictions in a stylized way. The impact of carbon taxes on the net carbon emissions of the industries is analyzed in Section 4.1, and the effects on GDP and trade flows are shown in Section 4.2. To achieve these results, we also considered two different carbon-equivalence measures (GWP and GTP). Furthermore, the industry "Meat \& Dairy" was disaggregated into three groups: Beef, Pork \& Chicken, and Dairy. This makes it possible to analyze in detail the different impacts, comparing the other effects of the use of GWP and GTP.

The model includes the interdependent structure of countries and trade flows in the GTAP database. The results are based on percentage relative changes from the baseline scenario (given by the data) and the estimated counterfactual situations from the simulated scenario shocks. Therefore, it was assumed that the baseline scenario reflects the current policy configuration (in terms of trade, environmental, and agricultural policies). Remarkably, Brazil's trade policies are characterized by a higher degree of protectionism, and the strengthened agricultural policy is focused on increasing productivity, output, and exports. In addition, the Brazilian Agricultural Ministry uses a support policy with rural credit, minimum prices, and interest rates below the market average (subsidies) [1,23].

On the other hand, in terms of Brazil's environmental policies, the main instrument used is the national FCCI. To provide evidence on both economic and environmental outcomes, the counterfactual analysis includes the main changes in an environmental setting represented by the main multilateral initiative, the Paris Agreement on Climate Change (also referred to as "COP21"). In this regard, the following section presents the results of the alternative scenario simulations for six industrial sectors (Meat, Pork \& Chicken, Grains \& Crops, Energy, Forestry, and Industry \& Services). As the focus of this paper is sectoral, the effects on macroeconomic aggregates, exports, and gross production are presented only for the agricultural sectors.

\subsection{GHG Emissions}

The initial effects of carbon rates on emissions from the Meat \& Dairy, Grains \& Crops, Energy, and Industry \& Services sectors are presented in Tables 6 and 7. From these tables, it is possible to identify how the different strategies of pricing the GHG emissions generate other effects on each individual sector and all sectors in Brazil. As expected, the carbon taxes applied to GWP emissions have more significant impacts than the GTP on the activities that have higher methane emissions. Even after the same carbon tariff is applied to each of the sectors in the Meat \& Dairy industry, there is a substitution effect between the production of beef and dairy and the production of poultry and pork. This results in a more intense reduction in cattle and dairy farming (Pigou's well-being effect) and increases the emissions from the production of other meats, such as chicken and pork. As a result of these changes, there is a net reduction in GHG emissions. As an example of this, in Scenario 1, the carbon tariffs are the same for all sectors of the Meat \& Dairy industry (Beef, Pork \& Chicken, and Dairy). Still, the observed effects have different intensities according to the indicator (GWP or GTP) and their link with the other economic sectors in Brazil. This occurs because, in the structure of the GTAP, the industries affected directly by the shock present the most significant variation. However, the way these industries are linked with the others in the economic system triggers indirect effects. Therefore, for all alternatives in this scenario, it is possible to observe a more significant reduction in the production of Beef \& Dairy than in the production of Chicken \& Pork and the other sectors. 
Table 6. Variations (\%) in GWP and GTP emissions by agricultural industries in all scenarios.

\begin{tabular}{|c|c|c|c|c|c|c|c|c|}
\hline \multirow{2}{*}{ Scenario and Carbon-Tax Amount } & \multicolumn{2}{|c|}{ Beef } & \multicolumn{2}{|c|}{ Pork \& Chicken } & \multicolumn{2}{|c|}{ Dairy } & \multicolumn{2}{|c|}{ Grains \& Crops } \\
\hline & GWP & GTP & GWP & GTP & GWP & GTP & GWP & GTP \\
\hline $1-20$ & -11.9 & -2.7 & 1.7 & 1.6 & -1.4 & -0.3 & 0.7 & 0.2 \\
\hline $1-40$ & -24.5 & -6.0 & 1.0 & 0.9 & -3.0 & -0.9 & 1.6 & 0.4 \\
\hline $1-60$ & -37.1 & -9.3 & 0.3 & 0.1 & -4.6 & -1.4 & 2.4 & 0.6 \\
\hline $2-20$ & 0.5 & 0.5 & 2.3 & 2.2 & 0.0 & 0.0 & 0.8 & 0.8 \\
\hline $2-40$ & 1.1 & 1.1 & 4.8 & 4.6 & 0.1 & 0.1 & 1.8 & 1.7 \\
\hline $2-60$ & 1.7 & 1.7 & 7.3 & 7.0 & 0.1 & 0.1 & 2.7 & 2.6 \\
\hline $3-20$ & -12.0 & -3.0 & 0.9 & 0.3 & -1.5 & -0.4 & -1.1 & -1.1 \\
\hline $3-40$ & -23.7 & -5.5 & 4.1 & 2.7 & -3.0 & -0.9 & -0.5 & -0.6 \\
\hline $3-60$ & -35.3 & -8.1 & 7.1 & 5.2 & -4.5 & -1.4 & 0.1 & 0.0 \\
\hline $4-20 / 40$ & -11.2 & -2.4 & 3.9 & 2.7 & -9.2 & -0.4 & 0.2 & -0.2 \\
\hline $4-20 / 60$ & -10.6 & -1.9 & 6.9 & 4.9 & -1.3 & -0.4 & 1.1 & 1.7 \\
\hline $4-40 / 60$ & -23.0 & -4.9 & 7.0 & 5.1 & -2.9 & -0.9 & 0.6 & 0.3 \\
\hline
\end{tabular}

Source: The authors based on results.

Table 7. Variations (\%) in GWP and GTP emissions by the Energy, Forestry, and Industry \& Services sectors and the total in all scenarios.

\begin{tabular}{ccccccccc}
\hline \multirow{2}{*}{ Scenario and Carbon-Tax Amount } & \multicolumn{2}{c}{ Energy } & \multicolumn{2}{c}{ Forestry } & \multicolumn{2}{c}{ Ind. \& Serv. } & \multicolumn{2}{c}{ Total } \\
\cline { 2 - 8 } & GWP & GTP & GWP & GTP & GWP & GTP & GWP & GTP \\
\hline $1-20$ & 0.6 & 0.1 & -0.1 & 0.0 & 0.1 & 0.0 & -2.4 & -0.2 \\
$1-40$ & 1.3 & 0.3 & -0.2 & -0.1 & 0.2 & 0.1 & -5.0 & -0.4 \\
$1-60$ & 2.0 & 0.5 & -0.3 & -0.1 & 0.3 & 0.1 & -7.6 & -0.6 \\
$2-20$ & -6.8 & -6.6 & 0.1 & 0.1 & 0.2 & 0.2 & -1.7 & -2.5 \\
$2-40$ & -14.5 & -14.0 & 0.2 & 0.2 & 0.4 & 0.4 & -3.7 & -5.2 \\
$2-60$ & -22.1 & -21.3 & 0.2 & 0.2 & 0.6 & 0.1 & -5.6 & -8.0 \\
$3-20$ & -7.7 & -8.1 & 0.3 & 0.3 & 0.5 & 0.4 & -4.6 & -3.2 \\
$3-40$ & -14.2 & -15.0 & 0.2 & 0.4 & 0.8 & 0.6 & -9.1 & -6.1 \\
$3-60$ & -20.6 & -21.9 & 0.2 & 0.4 & 1.1 & 0.8 & -13.5 & -9.0 \\
$4-20 / 40$ & -15.1 & -15.5 & 0.3 & 0.4 & 0.7 & 0.6 & -6.7 & -6.0 \\
$4-20 / 60$ & -22.5 & -22.9 & 0.4 & 0.4 & 0.8 & 0.7 & -8.4 & -8.7 \\
$4-40 / 60$ & -21.6 & -22.4 & 0.3 & 0.4 & 1.0 & 0.8 & -10.9 & -8.8 \\
\hline
\end{tabular}

Source: The authors based on results.

For these industries, the production of Beef (Dairy) decreased by between $-11.9 \%$ and $-37.1 \%(-1.4 \%$ and $-4.6 \%)$ considering GWP and between $-2.7 \%$ and $-9.3 \%(-0.3 \%$ and $-1.4 \%$ ) considering GTP. The production of Chicken \& Pork, even with carbon taxes, has increased due to a change in relative prices in the Meat \& Dairy market.

Due to the growth of this industry, the model shows an increase in the production of the Grains \& Crops and Energy industries, resulting in higher emissions for these last two groups. For the Brazilian economy in Scenario 1, there is a reduction in carbon emissions considering GWP, from $-2.4 \%$ to $-7.6 \%$, while for GTP, the reduction is from $-0.2 \%$ to $-0.6 \%$. Reductions in GHG emissions in terms of GTP are less sensitive to changes in tariffs when compared with GWP. As discussed earlier, this is mainly due to Brazilian GHG standards and the higher share of methane.

In the second scenario, the emissions pricing policy was simulated only for the Energy industry. In this case, two critical issues related to the GTAP model must be considered. First, there is a proportional relationship between a sector's emissions and the average energy use for each industry. Second, the production of the Energy industry assumes a CES function of energy and value addition [32,45]. Due to this proportional relationship and the reduced participation of methane in the total emissions of the Energy industry, the results are very similar for both GHG measures.

As mentioned before, the changes in GHG emissions in terms of GWP and GTP are similar due to the imposition of equal tariffs only on the Energy industry in Brazil. As a 
result, there is a reduction in the GWP emissions of between $-6.8 \%$ and $-22.1 \%$ and a reduction in the GTP emissions of between $-6.6 \%$ and $-21.3 \%$. In the Brazilian economy, Scenario 2 shows a reduction in GWP of between $-1.7 \%$ and $-5.6 \%$ and a reduction in GTP of between $-2.5 \%$ and $-8.0 \%$. For the Meat \& Dairy industry, Chicken \& Pork production presents a more significant increase in GHG emissions for both indicators.

In Scenario 3, carbon taxes on emissions for all industries of the economy were simulated, considering the same amount per ton of GHGs. The carbon taxes in this scenario mainly reduce the emissions from the Energy and Beef \& Dairy industries for both indicators (GWP and GTP). In contrast, even with an equivalent carbon tax, there is an incentive to increase GHG emissions from Pork \& Chicken production due to the substitution effect between Pork \& Chicken and Beef production. As a result, the emissions from the Energy industry reduce by between $-7.7 \%$ and $-20.6 \%$ with respect to GWP and between $-8.1 \%$ and $-21.9 \%$ with respect to GTP. For the Beef industry, there is a reduction in GWP emissions of between $-12.0 \%$ and $-35.3 \%$ and a decrease in GTP emissions of between -3.0 and $-8.1 \%$. Although it experiences a smaller decline, the Dairy industry's GWP emissions fall by between $-1.5 \%$ and $-3.5 \%$ and its GTP emissions fall by between $-0.4 \%$ and $-1.4 \%$.

The third scenario also shows the difference between the used indicators (GWP and GTP) regarding the sensitivity of different measures in pricing carbon emissions for the various segments of the economy. In most cases, the variations measured in GWP are greater than the variations in terms of GTP. As a result, the carbon tax effects on GHG emissions using GWP have a more intense impact on activities related to Beef and Dairy, mainly because these activities emit more methane.

In the case of GHG emissions measured in GWP, the simulations from Scenario 3 show a reduction of between $-4.6 \%$ and $-13.5 \%$ for the entire Brazilian economy. For GTP, the variations are between $-3.2 \%$ and $-9.0 \%$. When comparing the results between the two indicators, it is possible to observe a smaller variation in emissions with respect to GTP for most industries. For both indicators, the industries most impacted by the application of the carbon tariff are Energy and Meat \& Dairy. In the case of the Energy industry, there are no essential differences between GWP and GTP. However, in the Meat \& Dairy industry, the variations are smaller in the case of GTP. Therefore, considering equal applied carbon taxes, GTP seems to be more appropriate than GWP because it does not penalize a relevant sector of the Brazilian economy with greater intensity.

The last scenario (Scenario 4) simulates different tariffs between industries of the Brazilian economy. The central idea is to not penalize agricultural activities, which have lower profitability and carry greater risk than the other economic activities. Three forms of collection were defined: in the first option of Scenario 4 (4-20/40), a $\$ 20 / t$ tariff was applied to carbon emissions for the Meat \& Dairy and Grains \& Crops industries and a $\$ 40 / \mathrm{t}$ tariff was applied to the Energy and Industry \& Services industries. Similarly, the two other alternatives (4-20/40) and (4-40/60) apply lower carbon taxes to the agricultural sectors and higher taxes to the Energy and Industry \& Services industries.

The different carbon taxes have dissimilar effects on the industries and the economy compared with the previous scenarios. Specifically, for the Meat \& Dairy industry, the decrease in GHG emissions is smaller when compared with Scenarios 1 and 3 for the same carbon taxes. On the other hand, because of the substitution effects, the Pork \& Chicken sector increases both its production and emissions, assuming the same carbon tax level and compared with the alternative scenarios.

In the fourth scenario, Pork \& Chicken production has a more significant variation in GHG emissions than all previous scenarios considering the same carbon tax applied to this industry. As for dairy production activities, there was a more significant reduction than in the earlier scenarios. Finally, the changes were more negative and intense in the Energy industry than in the previous scenarios for the same carbon tax. In general, the results for the Brazilian economy indicate that GHG emissions would be reduced by between $-6.7 \%$ and $-10.9 \%$ for GWP and by between $-6.0 \%$ and $-8.8 \%$ for GTP. 
In Scenarios 1 and 2, tariffs were applied only to the Meat \& Dairy and Energy industries. In Scenario 1, the tariffs on emissions were only applied to the Meat \& Dairy industries. These pricing simulation results imply lower emissions and an intense reduction in the production of Beef and Dairy. Therefore, Scenario 2 has the potential to create a greater inequality between the rural and the urban areas in Brazil. On the other hand, in Scenario 2, where tariffs are applied only to the Energy industry, there is an increase in the production of Meat \& Dairy and in the GHG emissions, which is also undesirable.

Scenario 3 seems to be more appropriate when we use GTP as an indicator of GHG emissions, mainly because this indicator assigns a lower weight to methane emissions, which are characteristic of beef and dairy production. The use of GTP, unlike GWP, allows for a less marked reduction in production and in emissions in the Beef \& Dairy industry, which allows for an equal carbon tax to be applied to all sectors. Scenario 4 seems to be more appropriate when GWP is used as an indicator for GHG emissions. In this case, the lower carbon tax for the agricultural sectors than for the other sectors allows us to compensate for the negative impacts on the production and emissions of these segments caused by the greater weight of the methane emissions that exists in the GWP.

In the next section, the different scenarios are analyzed in order to evaluate the effects of carbon taxes on Meat \& Dairy exportation and the Brazilian GDP.

\subsection{Economic Output and Trade Impacts}

This section describes the results from the simulations in terms of changes in Brazilian exports and GDP. Table 8 presents results for three industries important to Brazilian international trade (Beef, Pork \& Chicken, and Dairy) and the variations in exports and GDP. The last two columns indicate the variation in GDP considering GWP and GTP. Finally, for all scenarios, the impacts of these two sorts of carbon equivalence measures are presented.

Table 8. Changes in exports and GDP in terms of GWP and GTP in all scenarios (\%).

\begin{tabular}{|c|c|c|c|c|c|c|c|c|c|c|}
\hline \multirow{3}{*}{$\begin{array}{l}\text { Scenarios } \\
\text { Carbon-Tax }\end{array}$} & \multicolumn{8}{|c|}{ Exports } & \multirow{2}{*}{\multicolumn{2}{|c|}{ GDP }} \\
\hline & \multicolumn{2}{|c|}{ Beef } & \multicolumn{2}{|c|}{ Pork \& Chicken } & \multicolumn{2}{|c|}{ Dairy } & \multicolumn{2}{|c|}{ Total } & & \\
\hline & GWP & GTP & GWP & GTP & GWP & GTP & GWP & GTP & GWP & GTP \\
\hline $1-20$ & -73.9 & -16.5 & 3.9 & 3.7 & -16.8 & -3.6 & 1.5 & 0.4 & -0.3 & -0.1 \\
\hline $1-40$ & -152.1 & -37.1 & 2.6 & 2.0 & -37.3 & -10.9 & 3.0 & 0.8 & -0.5 & -0.1 \\
\hline $1-60$ & -230.2 & -57.9 & 1.3 & 0.5 & -57.8 & -18.1 & 4.4 & 1.2 & -0.8 & -0.2 \\
\hline $2-20$ & 5.1 & 4.9 & 5.5 & 5.4 & 5.5 & 5.3 & 2.4 & 2.3 & -0.9 & -0.8 \\
\hline $2-40$ & 10.4 & 10.4 & 11.3 & 11.3 & 11.1 & 11.1 & 4.9 & 4.9 & -1.8 & -1.8 \\
\hline $2-60$ & 16.5 & 16.7 & 17.9 & 18.2 & 17.6 & 17.9 & 7.7 & 7.8 & -2.8 & -2.8 \\
\hline $3-20$ & -74.9 & -15.9 & 2.3 & 0.6 & -18.2 & -5.3 & -1.0 & -2.4 & -0.3 & 0.0 \\
\hline $3-40$ & -144.2 & -32.2 & 10.3 & 6.7 & -29.6 & -6.0 & 4.1 & 1.1 & -1.8 & -1.2 \\
\hline $3-60$ & -213.8 & -45.8 & 18.1 & 12.9 & -41.2 & -5.7 & 9.1 & 4.6 & -3.3 & -2.3 \\
\hline $4-20 / 40$ & -68.5 & -13.3 & 9.7 & 6.6 & -10.9 & -0.4 & 2.4 & 0.2 & -1.4 & -0.9 \\
\hline $4-20 / 60$ & -61.5 & -8.5 & 16.9 & 12.1 & -3.9 & 5.0 & 5.6 & 3.0 & -2.5 & -1.9 \\
\hline $4-40 / 60$ & -137.6 & -26.75 & 17.4 & 12.7 & -22.5 & -0.11 & 7.3 & 3.7 & -2.9 & -2.1 \\
\hline
\end{tabular}

Source: The authors based on results.

In Table 8, the first scenario simulates carbon taxes only on the Meat \& Dairy industries. Therefore, the effects on exports in Scenario 1 are mainly concentrated in these segments. As a result, the Beef sector has the most negative impact on exports, followed by the Dairy sector. When considering GWP, beef exports were reduced from $-73.9 \%$ to $-230.2 \%$, while beef exports were reduced from $-16.5 \%$ to $-57.9 \%$ for GTP. In the case of GWP, Brazil changes from a Beef exporter to a Beef importer in Scenario 1-60. For the Dairy sector, exports also decreased by between $-16.8 \%$ and $-57.8 \%$ for GWP and between $-3.6 \%$ and $-18.1 \%$ for GTP in Scenario 1. However, Brazil is not a traditional dairy exporter (it is a traditional beef exporter) in the international market [59]. As a result of this pattern from 
the base scenario, after applying carbon taxes in Scenario 1, it is possible to observe the greatest losses in the Beef sector in the international market.

Brazil's total exports increased from $1.5 \%$ to $4.4 \%$ for GWP and from $0.4 \%$ to $1.2 \%$ considering GTP. Scenario 1 has the smallest variations in GDP, from $-0.3 \%$ to $-0.8 \%$ for GWP and from $-0.1 \%$ to $-0.3 \%$ for GTP. However, as previously mentioned, this scenario presents the negative aspect of pricing only in the Meat \& Dairy industry, changing the relative prices in the Brazilian economy and reducing the production, exports, and emissions for just one sector.

The results for the second scenario consider the changes in emissions in the Energy sector. In general, this scenario has an increase in Brazilian exports in the Meat \& Dairy sectors and total exports. There is a significant reduction in GDP (between $-0.8 \%$ and $-2.8 \%$ ) for both GWP and GTP in this scenario. On the one hand, this scenario promotes a reduction in emissions from energy generation. On the other hand, it increases the production, exports, and emissions of the Meat \& Dairy industries. This last aspect has a determining role for beef cattle production in deforestation in Brazil. The results reinforce the idea that higher beef production is associated with greater deforestation and more considerable emissions from the forestry sector.

In Scenario 3, equal tariffs on carbon emissions are applied to all industries. This scenario also observed the most considerable reductions in beef and dairy exports and the biggest increases in pork and chicken exports for both indicators (GWP and GTP). Beef exports decreased by between $-74.9 \%$ and $-213.8 \%$ for GWP and by between $-15.9 \%$ and $-45.8 \%$ for GTP. With less intensity, dairy exports decreased by between $-18.2 \%$ and $-41.2 \%$ for GWP and by between $-5.3 \%$ and $-6.0 \%$ for GTP. As can be seen, the negative effects on beef and dairy exports are relatively more intense than those observed in other scenarios. On the other hand, pork and chicken exports increased by between $2.3 \%$ and $18.1 \%$ for GWP and by between $0.6 \%$ and $12.9 \%$ for GTP. Again, the different beef and pork and chicken exports are due to the substitution effect on meat production.

For the Brazilian economy, this is one of the scenarios that foresees the greatest reductions in GDP, which can be reduced by up to $-3.3 \%$ for GWP and by up to $-2.3 \%$ for GTP. Despite a significant drop in beef and dairy exports and a predicted drop in GDP for this scenario, the total exports in Scenario 3 have grown by up to $9.1 \%$ for GWP and up to $4.6 \%$ for GTP. This scenario indicates that an equal carbon tax on the emissions from all segments may negatively affect strategic industries in terms of the export of such products as beef and dairy products.

In the fourth scenario, the pricing for GHG emissions is simulated by applying lower tariffs to the agricultural sectors than to the Energy and Industry \& Services industries. This alternative scenario is proposed to minimize the effect of carbon taxes on meat and milk, mainly when the GWP is used as a reference for total emissions. The beef exports decreased by between $-68.5 \%$ and $-137.6 \%$ for GWP in Scenario 4, although they decreased less than in Scenarios 1 and 3. Likewise, dairy exports fell by between $-3.9 \%$ and $-22.5 \%$, seeing only GWP emissions. As explained above, this mainly occurs because these industries are methane-intensive, and GWP penalizes these industries more than GTP does. Similarly, to Scenario 3, Pork \& Chicken sector exports and total exports have increased in Scenario 4, although the variation is minor. As a result of this dissimilar charge between industries, the GDP in this scenario has a smaller decrease than in Scenario 3, dropping from $-1.4 \%$ to $-2.9 \%$ in the fourth scenario for GWP.

Considering the results from Tables $6-8$, it is possible to observe the disadvantages of only charging for the emissions from one economic sector. Despite providing reductions in carbon emissions, Scenarios 1 and 2 increase the differences in income generation between the analyzed industries of the Brazilian economy, as it charges for emissions from only one segment. It is also possible to observe that Scenario 3 may be the most appropriate when using the GTP measure to estimate emissions. In this case, the reduction in GDP is not as intense as when using GWP, though the export of beef and dairy is also expected to drop. Finally, as discussed above, Scenario 4 is a combination of different carbon taxes 
on industries that seeks to minimize the effects of GWP on the activities that emit the most methane. Considering only the GWP alternative, the fourth scenario seems to be the most adequate in terms of cost distribution among the various economic sectors in Brazil. Although it presents a significant reduction in beef and dairy exports and the Brazil's GDP, it apparently redistributes this cost of carbon emissions among the different industries in a more balanced way than Scenario 3 for GWP.

\section{Discussion}

How does the taxation of carbon markets affect economic (gross production and international trade) and environmental (GHG emissions) outcomes? Our economic results relate to the amount of sectoral output and trade, while the environmental results that relate to GHG emissions in terms of GTP and GWP are shown in Figure 2. The fundamental theoretical assumption is that the shocks that apply to a specific industry affect the production cost based on the imposition of a tax. Hence, the objective of a firm is to minimize costs. The advantage of our general equilibrium framework is that it recognizes that productive sectors have heterogeneous emission coefficients. They depend fundamentally on the production function and the nature of the economic activity. Furthermore, the effects occur directly and by sector in the presence of sectoral shocks and indirectly through backward and forward input-output linkages.

\begin{tabular}{|c|c|c|c|}
\hline \multicolumn{4}{|c|}{ Implementation of carbon-based policies } \\
\hline $\begin{array}{l}\text { Environmental policy } \\
\text { instruments }\end{array}$ & Simulations & $\begin{array}{c}\text { Scenarios } \\
\text { (shocks on economic system) }\end{array}$ & Outcomes \\
\hline \multirow[t]{2}{*}{$\begin{array}{l}\text { Economic } \\
\text { Instruments (EI) }\end{array}$} & \multirow{2}{*}{$\begin{array}{l}\text { - It is supposed } \\
\text { implementation of } \\
\text { carbon tax on supply } \\
\text { (production) side }\end{array}$} & \multirow{2}{*}{$\begin{array}{l}\text { 1. Carbon tax on Meat and Dairy production; } \\
\text { other sectors carbon taxes are not applied } \\
\text { 2. Carbon tax on Energy industry } \\
\text { 3. Carbon tax on all industries, apart of forestry } \\
\text { sector } \\
\text { 4. Differentiated carbon tax on Meat and Dairy } \\
\text { regarding Energy and services industries }\end{array}$} & $\begin{array}{l}\text { Economic: } \\
\text { Production output } \\
\text { and trade }\end{array}$ \\
\hline & & & $\begin{array}{l}\text { - Environmental: GHG } \\
\text { emissions (GWP and } \\
\text { GTP) }\end{array}$ \\
\hline $\begin{array}{l}\text { Flexible } \\
\text { Command and } \\
\text { Control } \\
\text { Instruments } \\
\text { (FCCl) }\end{array}$ & $\begin{array}{l}\text { - Is the baseline scenario } \\
\text { (unchanged) }\end{array}$ & Varying among $20 \%, 40 \%$ or $60 \%$ & \\
\hline
\end{tabular}

Figure 2. Design of simulated carbon-based tax policies in the GTAP model. Source: the authors.

In the cost competitiveness approach, firms become more competitive as production costs fall (inputs are less expensive), investors expect returns as the cost of capital changes, and households depend on the variation in the budget constraint to change their consumption patterns. As the tax affects relative prices in the economy, firms can vary the amount produced to meet domestic and international demand, which requires inputs and primary factors of production. As the cost-minimizing strategy affects the quantity produced, this will generate direct and indirect effects on the market for factors of production, which, in turn, affect the level of capital investment and the level of household wages. These variations occur simultaneously with the changes in relative prices, whether domestic or international. Thus, the effects on the use of inputs in specific economic sectors affect the availability of resources to other sectors of the economy, propagating through intersectoral and international production chains. The environmental extension of the model assumes a relationship between the technical coefficients of emissions (dependent on the intensity with which economic sectors emit GHGs), the intersectoral links (technical requirements), and the relative prices of the economy.

Building on this CGE framework, this paper has proposed four scenarios of implementation of carbon-based policies focused on EIs. In this regard, as discussed above, Brazilian agriculture policies have enabled an increase in agri-food production. Still, they have also intensified concerns about agribusiness and environmental protection and climate change 
mitigation actions. While Brazilian environmental legislation seeks to control deforestation and the use of land not suitable for agriculture, the agricultural policy encourages a continuous increase in the area destined for production and natural resource exploitation. As a result, there is an increase in (and spread of) the environmental impacts of food production, not accompanied by specific policy instruments that allow for the mitigation of negative effects of agri-food production systems on the environment. Moreover, agricultural expansion is often related to increased deforestation, which may negatively affect the growth and sustainability of Brazilian agricultural and food exports in the coming years $[4,6,60]$.

Over the past few decades, Brazil has positioned itself as an essential driver of the international meat and dairy industries. At the same time, the country has been an active player in the multilateral discussions about agreements focused on sustainability and the control of carbon emissions worldwide. Therefore, the need to develop environmental and food policies capable of associating the sustainable growth of Brazilian agriculture with socio-environmental guidelines is fundamental to Brazil's trading position in the context of climate change.

The policy implications of the results presented suggest the need for a debate on the definition of a specific EI regarding the mitigation potential of Brazilian GHG emissions in the food industries where Brazil has comparative advantages. International evidence corroborates these results $[35,39]$, showing the relevance of adopting policies based on the carbon market as a mechanism to induce changes in agri-food production systems that allow for the amount of GHGs in the atmosphere to be reduced [61]. These instruments change relative prices in the Brazilian economy and can reduce GHG emissions, stimulating the adoption of clean technologies and production activities that emit less GHGs. As discussed above, carbon taxes not only reduce the production of beef-related deforestation in new agricultural areas but also partially change the whole sector's production towards other segments that emit less GHGs, such as the production of pork and chicken meat. Although these latter two are not directly linked to the expansion of new agricultural areas or associated with deforestation, this EI may minimize conflicts between agricultural and environmental issues in Brazil.

A relevant aspect of the international debate on climate change policies relates to $\mathrm{CO}_{2}$ equivalence measures, which tend to penalize economies with advantages in terms of meat-related industries and that engage in intense land-use activities. The counterpart of the total GHG emissions concerning the industrial structure is given by the different types of GHG, which have different sectoral coefficients according to the measure considered. The results reinforce the fact that the use of an EI with GWP and GTP measures produces distinct effects on total emissions, production, and trade. For the analyzed scenarios, the use of GWP always has a more intense impact on beef and milk production. For this reason, the taxation of all industries (Scenario 3) implies reducing not only beef exports but also changing Brazil's position from an exporter to a beef meat importer when GWP is used as a measure of GHG emissions.

Notwithstanding, the application of an EI on the industry level (Scenarios 3 and 4) restricts less than the GTP the urban economic activities and reduces more the urban economic activities in those industries with methane emissions. For example, the Energy industry had a similar production change for both indicators (GWP and GTP) when applying carbon taxes. However, there was a sharper drop for GWP for the beef and dairy industries than for GTP. In addition, the Industry \& Service sector, even when the GHG emissions were taxed, showed an increase in GHG emissions due to the change in the economy's relative prices.

Another relevant aspect evidenced in this study is the adjustment in the size of the carbon pricing policy in a sector-specific way. Adjusting the levels of environmental taxes generates results that vary in terms of economic and trade effects and the potential for reducing the amount of pollutants generated by Brazil in the international setting. In food production, trade, and consumption, meat chains are indirectly penalized by failing to consider emissions reduction targets measured in GWP. Including taxes on all industries 
(Scenario 3), emissions reduce less intensely with respect to GTP than with respect to GWP in beef and dairy production. The negative effect on exports is also lower for beef and dairy when using GTP than when using GWP.

As the environmental policy applied lower taxes to the Meat \& Dairy sector compared with others (Scenario 4), the results are more promising for the agri-food industry; the more significant the difference and the lower the carbon taxes applied to the agricultural sector in relation to the other industries, the larger size of the relative tax-driven results in terms of total output and GHG emissions. When taxed (Scenario 4, 20/60 per ton), the agricultural sector was less penalized, especially the beef and dairy industries. The negative economic impacts were also lower for beef and dairy exports.

To minimize the adverse effects on economic activity, particularly meat and dairy production, it is important to consider the possibility of a gradual introduction of carbon taxes on GHG emissions, allowing those industries more intensely affected by charging for GHG emissions a period of adaptation. It will enable farmers to adapt, adopt clean technologies, and/or reorganize their economic activities into less-GHG-emitting industries. The following section presents the main conclusions of this research and the contributions, which are related to reductions in carbon emissions obtained by applying carbon taxes to GHG emissions.

\section{Conclusions}

This article analyzed the effects of the implementation of economic instruments based on carbon taxation on strategic industries of the Brazilian economy in terms of economic (GDP and exports) and environmental (GHG emissions for both the GWP and GTP measures) outcomes. To identify the effects of this policy implementation, a strategy was adopted to compare four different environmental policies scenarios evaluating the degree of effectiveness at reducing emissions.

In terms of climate policies, the article contributes to broadening the discussion and presenting different strategies to reduce carbon emissions in Brazil. Although Brazil significantly reduced its GHG emissions from 2005 to 2018 for both GWP (-44\%) and GTP $(-54 \%)$ (see Table 1) with a consistent increase in meat exports, this emission pattern will be difficult to maintain. Furthermore, the increase in production and exportation of meat, particularly beef, has increased pressure on forest areas to be converted into pasture areas. In this sense, the present study presents a broad set of Economic Instruments to complement current environmental and agricultural policies, which might allow for a sustainable reduction in carbon emissions.

Brazil has been a signatory to the Paris Agreement since 2015 and uses the GWP to measure sectoral GHG emissions, define its environmental policies, and pursue the targets for reducing GHG emissions set out in the Paris Agreement. However, as discussed in the results, the GWP penalizes those industries that emit a higher proportion of methane more than other industries, which is associated with a policy of charging for emissions that severely harms the production and export of beef.

The results presented suggest that using the GTP measure for carbon taxes may be an alternative strategy to minimize the effects of local environmental policies on charging for emissions and reduce the negative impact on beef production and exportation. Another alternative, although less effective from the point of view of the meat industry, is to keep charging for GHG emissions using GWP but to impose lower tariffs on the agricultural sector. Adopting more strict measures to reduce GHG emissions may place Brazil in a prominent position in the global context as a proactive country in global warming mitigation. However, as discussed earlier in this study, Brazil must apply environmental policy instruments to all economic industries without rendering unfeasible strategic industries, such as the beef industry.

A limitation of this study was the focus on modeling the effect of the carbon tax on the production system. Therefore, the estimated results consider the impact on the purely economic compensatory relations between the market price and the supply and demand by 
economic agents within the multiregional structure of the CGE model. In this sense, future studies can explicitly incorporate the energy component capable of measuring the effects of taxation on an emission source instead of the final product of the productive activity. Despite this, the main cause-and-effect mechanism was incorporated into this analysis since the model assumes that changes in relative prices are determined by economic agents ${ }^{\prime}$ decision processes and behavior.

Finally, an appropriate debate on the use of a diverse range of environmental policy instruments may allow Brazil to reduce its GHG emissions and minimize the negative impacts upon production, exports, and economic growth. For this reason, cooperation between policy-makers from different areas, such as economics, trade, agriculture, and the social sciences, is essential.

Author Contributions: Funding acquisition, A.M.A.; Investigation, E.R.S.; Methodology, E.R.S.; Project administration, A.M.A.; Software, E.R.S.; Supervision, A.M.A.; Writing-original draft, A.M.A.; Writing - review \& editing, E.R.S. All authors have read and agreed to the published version of the manuscript.

Funding: This research was funded by Coordenação de Aperfeiçoamento de Pessoal de Nível Superior grant number 88887.356519/2019-00.

Institutional Review Board Statement: Not applicable.

Informed Consent Statement: Not applicable.

Data Availability Statement: Not applicable.

Conflicts of Interest: The authors declare no conflict of interest.

\section{References}

1. Brasil. Política Agrícola. Política Agrícola no Brasil. 2020. Available online: https://www.gov.br/agricultura/pt-br/assuntos/ politica-agricola (accessed on 27 February 2021). (In Portuguese)

2. Lynch, J. Availability of disaggregated greenhouse gas emissions from beef cattle production: A systematic review. In Environmental Impact Assessment Review; Elsevier Inc.: Amsterdam, The Netherlands, 2019; Volume 76, pp. 69-78. [CrossRef]

3. SEEG. Sistema de Emissões de Gases de Efeito Estufa. 2020. Available online: https:/ / www.seeg.eco (accessed on 27 February 2021). (In Portuguese).

4. Margulis, S. Causes of Deforestation of the Brazilian Amazon; World Bank Publications: Washington, DC, USA, 2004. [CrossRef]

5. Filho, H.S.R.; Ferreira, M.E.P. A taxa de câmbio e os ajustes no saldo da balança comercial brasileira: Uma análise setorial da Curva J. Nova Econ. 2016, 26, 887-907. [CrossRef]

6. Carvalho, T.S.; Domingues, E.P.; Horridge, J.M. Controlling deforestation in the Brazilian Amazon: Regional economic impacts and land-use change. Land Use Policy 2017, 64, 327-341. [CrossRef]

7. Johansson, D.J.A. Economics- and physical-based metrics for comparing greenhouse gases. Clim. Chang. 2011, 110, 123-141. [CrossRef]

8. Persson, U.M.; Johansson, D.J.A.; Cederberg, C.; Hedenus, F.; Bryngelsson, D. Climate metrics and the carbon footprint of livestock products: Where's the beef? Environ. Res. Lett. 2015, 10, 034005. [CrossRef]

9. Lynch, J.; Cain, M.; Pierrehumbert, R.; Allen, M. Demonstrating GWP: A means of reporting warming-equivalent emissions that captures the contrasting impacts of short- and long-lived climate pollutants. Environ. Res. Lett. 2020, 15, 044023. [CrossRef]

10. Bobokhonov, A.; Pokrivcak, J.; Rajcaniova, M. The impact of agricultural and trade policies on price transmission: The case of Tajikistan and Uzbekistan. J. Int. Trade Econ. Dev. 2017, 26, 677-692. [CrossRef]

11. Desjardins, P.; Polèse, M.; Shearmur, R. The Evolu on of Canada's Regional Economies: Structural Pa erns, Emerging Trends and Future Challenges Legal Deposit: Bibliothèque et Archives nationales du Québec, 2013 Bibliothèque et Archives Canada. Available online: www.ucs.inrs.ca/ucs/publications/collections/rapports-et-notes-de-recherche (accessed on 27 February 2021).

12. Henderson, B.; Golub, A.; Pambudi, D.; Hertel, T.; Godde, C.; Herrero, M.; Cacho, O.; Gerber, P. The power and pain of market-based carbon policies: A global application to greenhouse gases from ruminant livestock production. Mitig. Adapt. Strateg. Glob. Chang. 2017, 23, 349-369. [CrossRef]

13. Van Veelen, B. Cash cows? Assembling low-carbon agriculture through green finance. Geoforum 2021, 118, 130-139. [CrossRef]

14. Myhre, G.; Shindell, D.; Pongratz, J. Anthropogenic and Natural Radiative Forcing. In Climate Change 2013: The Physical Science Basis. Contribution of Working Group I; Cambridge University Press: Cambridge, UK, 2013.

15. Maraqa, M.A.; Albuquerque, F.D.B.; Alzard, M.H.; Chowdhury, R.; Kamareddine, L.A.; el Zarif, J. GHG Emission Reduction Opportunities for Road Projects in the Emirate of Abu Dhabi: A Scenario Approach. Sustainability 2021, 13, 7367. [CrossRef] 
16. D'Aurea, A.P.; Cardoso, A.d.; Guimarães, Y.S.R.; Fernandes, L.B.; Ferreira, L.E.; Reis, R.A. Mitigating Greenhouse Gas Emissions from Beef Cattle Production in Brazil through Animal Management. Sustainability 2021, 13, 7207. [CrossRef]

17. Sajid, M.J.; Qiao, W.; Cao, Q.; Kang, W. Prospects of industrial consumption embedded final emissions: A revision on Chinese household embodied industrial emissions. Sci. Rep. 2020, 10, 287-309. [CrossRef] [PubMed]

18. Vasel-Be-Hagh, A.; Ting, D.S.K. (Eds.) Environmental Management of Air, Water, Agriculture, and Energy; CRC Press: Boca Raton, FL, USA, 2020. [CrossRef]

19. Pan, C.; Shrestha, A.K.; Wang, G.; Innes, J.L.; Wang, K.X.; Li, N.; Li, J.; He, Y.; Sheng, C.; Niles, J. A Linkage Framework for the China National Emission Trading System (CETS): Insight from Key Global Carbon Markets. Sustainability 2021, 13, 7459. [CrossRef]

20. Miceikienè, A.; Gesevičienè, K.; Rimkuvienè, D. Assessment of the Dependence of GHG Emissions on the Support and Taxes in the EU Countries. Sustainability 2021, 13, 7650. [CrossRef]

21. Zabrodskyi, A.; Šarauskis, E.; Kukharets, S.; Juostas, A.; Vasiliauskas, G.; Andriušis, A. Analysis of the Impact of Soil Compaction on the Environment and Agricultural Economic Losses in Lithuania and Ukraine. Sustainability 2021, 13, 7762. [CrossRef]

22. Mohebbi, G.; Bahadori-Jahromi, A.; Ferri, M.; Mylona, A. The Role of Embodied Carbon Databases in the Accuracy of Life Cycle Assessment (LCA) Calculations for the Embodied Carbon of Buildings. Sustainability 2021, 13, 7988. [CrossRef]

23. Kroeger, M.E.; Meredith, L.K.; Meyer, K.M.; Webster, K.D.; de Camargo, P.B.; de Souza, L.F.; Tsai, S.M.; van Haren, J.; Saleska, S.; Bohannan, B.J.M.; et al. Rainforest-to-pasture conversion stimulates soil methanogenesis across the Brazilian Amazon. ISME J. 2021, 15, 658-672. [CrossRef]

24. Gurgel, A.C.; Paltsev, S.; Breviglieri, G.V. The impacts of the Brazilian NDC and their contribution to the Paris agreement on climate change. Environ. Dev. Econ. 2019, 24, 395-412. [CrossRef]

25. Brasil and C. I. S. M. do Clima. Plano Nacional Sobre Mudança do Clima-PNMC. Brasilia—Distrito Federal, Brazil. 2008. Available online: http://www.mma.gov.br/estruturas/smcq_climaticas/_arquivos/plano_nacional_mudanca_clima.pdf (accessed on 27 February 2021).

26. Lucena, A.F.P.; Clarke, L.; Schaeffer, R.; Szklo, A.; Rochedo, P.R.R.; Nogueira, L.P.P.; Daenzer, K.; Gurgel, A.; Kitous, A.; Kober, T. Climate policy scenarios in Brazil: A multi-model comparison for energy. Energy Econ. 2016, 56, 564-574. [CrossRef]

27. Pereda, P.C.; Lucchesi, A.; Garcia, C.P.; Palialol, B.T. Neutral carbon tax and environmental targets in Brazil. Econ. Syst. Res. 2018, 31, 70-91. [CrossRef]

28. Gurgel, A.C.; Paltsev, S. Costs of reducing GHG emissions in Brazil. Clim. Policy 2013, 14, 209-223. [CrossRef]

29. Santos, L.; Garaffa, R.; Lucena, A.F.P.; Szklo, A. Impacts of Carbon Pricing on Brazilian Industry: Domestic Vulnerability and International Trade Exposure. Sustainability 2018, 10, 2390. [CrossRef]

30. Nasirov, S.; O’Ryan, R.; Osorio, H. Decarbonization Trade-offs: A Dynamic General Equilibrium Modeling Analysis for the Chilean Power Sector. Sustainability 2020, 12, 8248. [CrossRef]

31. Cain, M.; Lynch, J.; Allen, M.R.; Fuglestvedt, J.S.; Frame, D.J.; Macey, A.H. Improved calculation of warming-equivalent emissions for short-lived climate pollutants. NPJ Clim. Atmos. Sci. 2019, 2, 1-7. [CrossRef] [PubMed]

32. Chen, Z.; Chen, D.; Kwan, M.; Chen, B.; Gao, B.; Zhuang, Y.; Li, R.; Xu, B. The control of anthropogenic emissions contributed to 80\% of the decrease in $\mathrm{PM}_{2.5}$ concentrations in Beijing from 2013 to 2017. Atmos. Chem. Phys. 2019, 19, 13519-13533. [CrossRef]

33. Walmsley, T.; Narayanan, B.; Aguiar, A.; McDougall, R. Building a global database: Consequences for the national I-O data. Econ. Syst. Res. 2018, 30, 478-496. [CrossRef]

34. Antimiani, A.; Fusacchia, I.; Salvatici, L. GTAP-VA: An Integrated Tool for Global Value Chain Analysis. J. Glob. Econ. Anal. 2018, 3, 69-105. [CrossRef]

35. Fraser, I.; Waschik, R. The Double Dividend hypothesis in a CGE model: Specific factors and the carbon base. Energy Econ. 2013, 39, 283-295. [CrossRef]

36. De Azevedo, T.R.; Junior, C.C.; Junior, A.B.; Cremer, M.d.S.; Piatto, M.; Tsai, D.S.; Barreto, P.; Martins, H.; Sales, M.; Galuchi, T.; et al. SEEG initiative estimates of Brazilian greenhouse gas emissions from 1970 to 2015. Sci. Data 2018, 5, 1-43. [CrossRef] [PubMed]

37. Van Meijl, H.; van Rheenen, T.; Tabeau, A.; Eickhout, B. The impact of different policy environments on agricultural land use in Europe. Agric. Ecosyst. Environ. 2006, 114, 21-38. [CrossRef]

38. Rutherford, T.F. Climate-Linked Tariffs: Practical Issues 1 Thinking Ahead on International Trade (TAIT) Climate-Linked Tariffs: Practical Issues. 2010. Available online: www.graduateinstitute.ch/ctei (accessed on 18 July 2021).

39. Frey, M. Assessing the impact of a carbon tax in Ukraine. Clim. Policy 2016, 17, 378-396. [CrossRef]

40. Allen, D.T.; Sullivan, D.W.; Zavala-Araiza, D.; Pacsi, A.P.; Harrison, M.; Keen, K.; Fraser, M.P.; Hill, A.D.; Lamb, B.K.; Sawyer, R.F.; et al. Methane emissions fro(m process equipment at natural gas production sites in the United States: Liquid unloadings. Environ. Sci. Technol. 2015, 49, 641-648. [CrossRef]

41. Allen, D.T. Emissions from oil and gas operations in the United States and their air quality implications. J. Air Waste Manag. Assoc. 2016, 66, 549-575. [CrossRef]

42. Boucher, O.; Reddy, M.S. Climate trade-off between black carbon and carbon dioxide emissions. Energy Policy 2008, 36, 193-200. [CrossRef]

43. Brewer, T.L. Black carbon emissions and regulatory policies in transportation. Energy Policy 2019, 129, 1047-1055. [CrossRef] 
44. SEEG. Emissões Totais I SEEG—Sistema de Estimativa de Emissão de Gases. Emissões Totais de Gases de Efeito Estufa; 2020. Available online: http:/ / plataforma.seeg.eco.br/total_emission\# (accessed on 20 July 2021).

45. Schmitt, D.J. Ministro Edson Duarte Secretário-Executivo Substituto Secretário Departamento de Florestas e Combate ao Desmatamento Presidente Michel Temer Ministério do Meio Ambiente República Federativa do Brasil Secretaria Executiva Romeu Mendes do Carmo Secretaria de Mudança do Clima E Florestas. 2018. Available online: http://www.mma.gov.br/ publicacoes-mma (accessed on 18 July 2021).

46. G. F. do B. Ministério do Meio Ambiente. Plano de Ação para Prevenção e Controle do Desmatamento na Amazônia Legal (PPCDAm). Brasília, DF. 2004. Available online: http://redd.mma.gov.br/images/central-de-midia/pdf/artigos/enreddppcdam.pdf (accessed on 20 July 2021).

47. G. F. do B. Ministério do Meio Ambiente. Planos de Ação para Prevenção e Controle do Desmatamento na Amazônia Legal e no Cerrado-PPCDAm e PPCerrado Comissão Executiva para Controle do Desmatamento Ilegal e Recuperação da Vegetação. Brasília, DF. 2019. Available online: http:/ / combateaodesmatamento.mma.gov.br/images/Doc_ComissaoExecutiva/BalanoPPCDAm-e-PPCerrado_2019_aprovado.pdf (accessed on 20 July 2021).

48. Civil, C.; Mapa, M.D. Plano Setorial de Mitigação e de Adaptação às Mudanças Climáticas para a Consolidação de uma Economia de Baixa Emissão de Carbono na Agricultura-Plano de Agricultura de Baixa Emissão de Carbono (Plano ABC)-Versão Preliminar 20 Maio; Ministerio da Agricultura: Brasilia, Brazil, 2011.

49. Bergquist, D.A.; Cavalett, O.; Rydberg, T. Participatory emergy synthesis of integrated food and biofuel production: A case study from Brazil. Environ. Dev. Sustain. 2011, 14, 167-182. [CrossRef]

50. Aguiar, A.; Narayanan, B.; McDougall, R. An Overview of the GTAP 9 Data Base. J. Glob. Econ. Anal. 2016, 1, 181-208. [CrossRef]

51. Hertel, T.W. Global Trade Analysis: Modeling and Applications; Press Syndicate of the University of Cambridge: Cambridge, UK, 1997.

52. Narayanan, B. Chapter 3: What's New in GTAP 9. May 2015. Available online: https://www.gtap.agecon.purdue.edu/resources/ res_display.asp?RecordID $=4820$ (accessed on 18 July 2021).

53. Feijó, F.T.; Júnior, S.P. O Protocolo De Quioto E O Bem-Estar Econômico No Brasil—Uma Análise Utilizando Equilíbrio Geral Computável. Anál. Econ. 2009, 27, 127-154. [CrossRef]

54. Röös, E.; Sundberg, C.; Tidåker, P.; Strid, I.; Hansson, P.A. Can carbon footprint serve as an indicator of the environmental impact of meat production? Ecol. Indic. 2013, 24, 573-581. [CrossRef]

55. Tourinho, O.A.F.; da Motta, R.S.; Alves, Y.L.B. Uma Aplicação Ambiental de um Modelo de Equilíbrio Geral. 2003. Available online: http:/ / repositorio.ipea.gov.br/handle/11058/2921 (accessed on 18 July 2021).

56. Tol, R.S.J. A social cost of carbon for (almost) every country. Energy Econ. 2019, 83, 555-566. [CrossRef]

57. Pigou, A.C. Some Problems of Foreign Exchange. Econ. J. 1920, 30, 460-472. Available online: https://www.jstor.org/stable/2222 870 (accessed on 20 July 2021). [CrossRef]

58. Nong, D. Development of the electricity-environmental policy CGE model (GTAP-E-PowerS): A case of the carbon tax in South Africa. Energy Policy 2020, 140, 111375. [CrossRef]

59. Hubbard, C.; Alvim, A.M.; Garrod, G. Brazilian Agriculture as a Global Player. EuroChoices 2017, 16, 3-4. [CrossRef]

60. Filho, J.B.d.F.; Ribera, L.; Horridge, M. Deforestation Control and Agricultural Supply in Brazil. Am. J. Agric. Econ. 2015, 97, 589-601. [CrossRef]

61. Säll, S. Environmental food taxes and inequalities: Simulation of a meat tax in Sweden. Food Policy 2018, 74, 147-153. [CrossRef] 